\title{
Privatisation as a Tenet of Growth Employment and Redistribution Strategy and its Socio-Economic Impact on the Poor in Khayelitsha
}

\author{
Mr Joao M Domingos \\ Department of Public Management, \\ Cape Peninsula University of Technology, South Africa \\ Professor William Fox \\ Department of Public Management, \\ Cape Peninsula University of Technology, Cape Town, South Africa
}

\section{Doi:10.19044/esj.2018.v14n31p351 URL:http://dx.doi.org/10.19044/esj.2018.v14n31p351}

\begin{abstract}
This paper seeks to present the macro-economic impact of privatisation in the Western Cape as perceived by its proponents and detractors, nationally and internationally. It investigates the effects and factors which influence privatisation. The study was conducted in the township of Khayelitsha. The sites were randomly selected and included Site C, Site B, ElithaPark, Macassar and MandelaPark. An in-depth literature review was conducted to investigate the macro-economic policy of Growth Employment and Redistribution Strategy (GEAR) and its tenet, privatisation. The socio-economic impacts of privatisation on the Khayelitsha communities were investigated by posing four questions. The researcher employed qualitative and quantitative research methodology to establish the opinions of the participants. Two types of data analysis were used namely: structural and interpretational. These techniques were appropriate for the study because they explored the feelings of the recipients of government policies. The result of the study revealed that privatisation is not creating jobs as expected and that economic growth does not benefit the poor. The research revealed the financial inability of the people to afford basic services. The Khayelitsha community prefer services rendered by government instead of the private sector. The findings of the statistical analysis indicated the respondents' dissatisfaction with government's privatisation objectives.

The researchers concludes that it is necessary to take into account that government in principle has the interests of the citizens at heart. However, its macro-economic policy is not having the desired results.
\end{abstract}


Keywords: Privatisation, GEAR, Khayelitsha, Globalisation, Unemployment, sustainable development

\section{INTRODUCTION}

The 1994 elections ushered in a new, exciting and challenging era for the South African society. The democratic government had inherited a discriminatory socio-economic system and a disorganised politicoadministrative framework, yet expectations for this government to deliver an improved quality of life were immense (Luiz, 2000).

The need for new and relevant macro-economic policies such as the Reconstruction and Development Programme (RDP) was originally proposed in 1994. Due to a lack of success in achieving its initial objectives, the RDP office was disbanded. In June 1996 the government adopted a new macro-economic policy framework called the Growth, Employment and Redistribution strategy (GEAR). GEAR which the government adopted in 1996, was singled out as having dire consequences on education, social services and employment. The main focus of GEAR was to reduce poverty and inequality by introducing a surge of economic growth.

According to Sikhakhane (2001), features of GEAR include economic growth, export-orientation and privatisation, otherwise known as the restructuring of state assets, de-regularisation and trade liberalisation. The key goals of GEAR were an economic growth of $6 \%$ in the year 2000; inflation of less than 10\%; above average employment growth within the economically active population; poverty reduction and job creation. All of these remain key goals of the government's economic policy (Knight, 2001).

The purpose of this paper is to present the macro-economic impact of privatisation in the Western Cape in particular, as perceived by its proponents and detractors, nationally and internationally. McGregor (1987) defines privatisation as a systematic transfer of appropriate functions, activities or property from the public to the private sector, where service productions and consumption can be regulated more efficiently by market and price mechanisms.

\section{A LITERATURE REVIEW}

Globalisation, initially known as imperialism and later neocolonialism, became the buzzword of the 1990s. Globalisation has made it possible to regulate or transform national and local economics, as argued by its proponents. Globalisation has disempowered anyone advocating anything remotely progressive in terms of social policy, from workers rights to ecological safeguards, people-centred development, gender equality and selfreliant economics (Bond, 2000). According to Suppermaniam (1999), whether defined as liberalisation, internationalisation, universalisation, or 
westernisation, the term "globalisation", in an economic sense, can be broadly defined as a process relating to the integration of economies worldwide, where the world economy is viewed as a single market and production area with regional or sub-sectors rather than a set of national economies linked by trade and investment flows.

For the purpose of this research, political globalisation, as identified by Taylor and Fleint, is the diffusion of a neo-liberal agenda, which promotes a state expenditure reduction, de-regularisation, privatisation and general open economies (Sikhakhane, 2001).

\subsection{ORIGINS OF GEAR}

According to Marais (1997) GEAR was drawn up by a cartel of progressive mainstream economists. The committee that was responsible for drafting GEAR comprised the following individuals: Andre Roux (Development Bank SA); Coordinator: IrajAbedian, (University of Cape Town); Coordinator: Andrew Donaldson (Department of Finance); Brian Khan (University of Cape Town); Ben Smith (University of Stellenbosh); DaleenSmal (South African Reserve Bank); Alan Hirsch (Department of Trade and Industry); Guy Mahone (Department of Labour); Ernie Van der Merwe (South African Reserve Bank); Ian Goldin (Development Bank of Southern Africa); Stephen Gelp (University of Durban Westville); Dirk Van Seventer (Development Bank Southern Africa); Servaas Van Den Berg (University of Stellenbosc); Luiz Pereira Da Silva (The World Bank); Richard Ketley (The Word Bank); as well as the Finance Minister, Trevor Manuel, then Deputy Minister, Gill Marcus, and the then acting Director General of Finance, Maria Ramos (Marais,1997).

The composition could betray a possibility of racial and ideological bias if race and class interests play a role in the development of policies. The racial composition of the committee cited above is telling if one has to take into account the initial goal of the ANC, the liberation of Africans in particular, and blacks in general from political and economic bondage, then it was not fulfilled as cited by Marais (1997).

Adelzadeh (1997) is of the view that the origin of GEAR is a foreigninfluenced policy intended to deal with complex domestic challenges and designed to satisfy the interests of big conglomerates. It is a response to the call of the neo-liberal financial, economic and political dimension of globalisation. It further asserts that the GEAR document was derived from a single model, that of the Reserve Bank.

\subsection{PRIVATISATION}

The privatisation processes can bring both positive and negative effects to the development of economies. 


\subsubsection{Privatisation: negative effects}

Privatisation impacts on the loss of employment as low technology and labour intensive productions shift to low wage countries. This raises the risk of a political backlash against free trade and capital flows. The loss of sovereignty over national objectives and priorities to multilateral, global rules may cause national priorities to be sidelined. The inadequacy and illpreparedness of a domestic national capacity to participate actively may lead to marginalisation and the inability of nationals to realise the benefits of globalisation. The rapid opening of markets will result in unrestricted entry of competing products and companies. This will affect domestic industries which are not mature enough to face the onslaught of competition (Suppermaniam, 1999). that it:

Further negative effects of privatisation cited by SADTU (2001) are

$>$ Undermines democracy and accountability to the people;

$>$ Enrich elites;

$>$ Encourages corrupt practices by many companies bidding for public spoils;

$>$ Erodes community safety nets and the human principle of solidarity by introducing the concepts and practices of excessive individualism greed;

$>$ Provides higher fees/tariffs and poorer services harming the quality of life for many

\subsubsection{Privatisation: positive effects}

Privatisation provides a conducive economic and business climate, which is necessary for continuous growth. It promotes a cost-effective business environment, encourages competition and enhances efficiency. The liberalisation of trade and investment regimes, as well as the deregulation and privatisation of government business activities, generates opportunities for the expansion of trade investment and technology flows. It obtains reciprocal market openings by trading partners particularly in the context of multilateral, regional and bilateral negotiations. It also promotes a wider choice of goods and services and reduced prices, which result from increased international competition and specialisation.

It allows for greater realisation of potential economies of scale of operations, technological and productivity improvements through crossborder specialisation and the utilisation of global factors of production and technology. It allows for more productive applications of capital worldwide, maximising rates of return on savings and investment that national opportunities are unable to provide (Suppermaniam, 1999). 


\subsection{PRIVATISATION IN SOUTH AFRICA}

The South African government has announced its plans to restructure the troubled economy. Privatisation was used as an instrument to help realise this goal, but can never be an end in itself. The assumption is that private management is inherently more efficient than state management. Economists in favour of privatisation also see a social welfare benefit in the process, as the spontaneous outcome of an economy organised by a network of competitive markets, free of government interference and social engineering (Brynard, 1993). Events show that privatisation cause rigging, collusion and monopolisation instead of the competitiveness that its prescribes.

Privatisation's introduction in the South African context accepted the same arguments that were used in the international context, namely a reduction in the scope of the state's involvement in the economy, as well as job losses because of retrenchments. Privatisation in South Africa started after successes elsewhere in the world, including those by the Thatcher government in the UK. Former State President, P W Botha, announced on 5 February 1988 that the NP government planned to restructure the economy by means of privatisation (De Villiers, 1988).

Privatisation in South Africa gained momentum when the National Party published its White Paper on Privatisation and Deregulation in 1987. Before that, the only major case of privatisation had taken place when the South African Coal, Oil and Gas Corporation (Sasol) was sold in 1979. By 1988 an Office for Privatisation had been established and numerous services, once provided by the government itself, were contracted out to private enterprises. These services included auditing, data processing, cleaning and maintenance, and repairs to official vehicles and equipment (Brynard, 1993).

Five public enterprises were earmarked and selected for privatisation. They were South African Iron and Steel Corporation (Iscor), the Electricity Supply Commission (Eskom), Phosphate Development Corporation (Foscor), South African Transport Services (Transnet), the Post Office and the Telecommunications Services. These parastatals were under the management of Minister Dawie de Villiers. Consultants and advisors from the private sector were asked to help the Minister with his evaluation of these enterprises (Sullivan, 1994). The first parastatal privatised was Iscor.

\subsection{PRIVATISATION AND CORRUPTION: THE SOUTH AFRICAN CONTEXT}

Corruption has become a major international concern and like in many other countries South Africa is not an exception. It is the topic of international conferences, policy forums and ministerial speeches (Hawley, 2000). There is always somebody who pays, and international business is generally the main source of corruption (Hawley, 2000). Multi-nationals 
bribe their way to win concessions associated with contracting and privatisation. The combination of multi-national engineered corruption and that of state officials, impacts on the development and eradication of poverty in South Africa(Vinten, 2003). Corruption is a major cause of poverty around the world. It occurs at all levels of society, from governments, civil society, judiciary functions, military and other services. The impact of corruption in poor countries on the poorer members of those societies is even more tragic (Hawley, 2000).

SADTU (2001) revealed that a number of chief executive officers (CEOs) have grown rich since 1994. Could this be attributed to privatisation which encourages corrupt practices? While CEOs earn millions at the expense of the working class, employers continue to exploit workers and to retrench them. Community safety nets and the human principle of solidarity have been eroded with the introduction of the concepts and practices of excessive individualism and greed, which is foreign to Africans and Africa's values. This has been further worsened by the introduction of fees, tariffs and poor service, which harm the quality of life for the poor. In African culture, the community has a strong influence on people's lives, particularly in improving the lives of the poorest by reducing poverty and creating an egalitarian society, which is the reason why government exists.

Jurgens (2006), citing Sapa reports that several prominent South Africans have been caught up in the arms deal controversy, including former ANC chief whip Tony Yengeni, Durban businessman Schabir Shaik, and former Deputy President Jacob Zuma. The European Aeronautical Defence Space Company (EADS) has admitted that it had "rendered assistance" to some 30 senior officials to obtain luxury vehicles. These officials included defence force Chief General SiphiweNyanda.

However, for corruption to exist there should be a corruptor and corruptee. To prove the correlation existing between the supplier and the buyer, a practical example is the company BAE. Besides being a supplier of weapons to South Africa, BAE is instrumental in advising the country on the privatisation of the national armaments industry. South Africa began wooing UK investment banks and institutional investors in a bid to raise more than $£ 4$ billion from privatisation. Up for grabs would be the country's key telecommunications companies, energy and airline assets. The government is also negotiating with BAE to help in commercialising the South African defence industry. This is a clear sign that there is a conflict of interest (Jurgens, 2006).

The stories relating to corruption with regards to the arms deal, Enron, as well as Travelgate continue to be documented. For multinationals, bribery enables companies to gain contracts particularly for public works and military equipment or concessions, which they would not otherwise have 
won, or to do so on more favourable terms (Hawley, 2000).

A few recent examples are worth mentioning because they are varied on the type of corruption involved, and they occurred very recently.

$>$ The first example is the US government, accused of outsourcing many contracts without an open bid process. Jim Hightower notes, "An analysis by the Times found that more than half of their outsourcing contracts are not open to competition. In essence, the Bushites choose the company and award the money without getting other bids. Prior to Bush, only $21 \%$ of federal contracts were awarded on a no-bid basis" (Hawley, 2000).

$>$ Another example around corruption which can be cited is Italy, where former Italian Prime Minister Silvio Berlusconi and some of his close associates were held on trial for various crimes and corruption cases (though Berlusconi himself has not, to date, been found guilty of any charges).

$>$ The recent example with the UN has been the oil for food scandal, where the headlines were about the corruption in the UN. In reality, the figure of $\$ 21$ billion or so of illicit funds blamed on the UN were exaggerations; it was $\$ 2$ billion; it was the UN Security Council (primarily US and UK) responsible for much of the monitoring; US kickbacks for corrupt oil sales were higher.

\subsection{SOCIO-ECONOMIC IMPACT OF PRIVATISATION IN SOUTH AFRICA}

In order to comprehend the extent of the impact of privatisation on poor communities, one needs to first understand the government's reason to privatise. From that, one should be able to assess whether it has failed or succeeded in achieving its preconceived objectives. According to Streak (2004), GEAR promised to reduce poverty and inequalities via a surge of economic growth. It further states that the key objectives were economic growth of $6 \%$ in the year 2000, inflation of less than $10 \%$, employment growth, and increased efficiency and effectiveness in services delivery. Those are very noble intentions on the surface.

SADTU's (2001) media release states that the privatisation of water excluded the poor households from access to safe drinking water. Furthermore, there could be losses of services, which are the most contentious issue when public services like water are privatised. In South Africa, 92772 households have had their water cut off, because of nonpayment. From 1996 to 2002 it included 75,400 in Cape Town and Tygerberg. Privatisation of electricity is often justified by pointing to the state's inefficiency to collect revenue. As a result, the enforced collection of bills in the poorest communities has severe social impacts because it leaves them without electricity. Thus the question remains who really benefits from 
privatisation?

MacDonald (2002) cites a survey by the HSRC in May 2001 that investigated the privatisation of municipal services. The results were as follows: $62 \%$ of those surveyed disagreed with privatisation of basic service, $17 \%$ were in favour and $21 \%$ were uncertain. The current privatisation wave implies a move towards a dangerous anti-people programme, which controls the very essence of humanity. Out of a population of 46 million people in South Africa, $48.5 \%$ of people were living in poverty in 2002 according to the national poverty line of R354 per month per adult equivalent (1995 value). In 2002, $23.8 \%$ of people were living on less than two US dollars a day, and $10.5 \%$ on less than one US dollar a day (UNDP, 2003).

Since partial privatisation and full commercialisation, Telkom has increased its tariffs for services used by poor households whilst it has decreased rates for rich families and businesses, especially with regard to international calls. At the same time, employment has been reduced. Privatisation can only worsen the conditions of the majority. Privatised social services promote national dependency on an increasingly globalised world and centres on accumulation and global market forces, which impose conditions to invest. The evidence suggests that privatisation undermines democracy and makes capitalism look good, but that it does little to alleviate poverty. It has not led to the empowerment of the indigenous private business sector. It contends that companies benefit economically and the GDP increased but this is because of the accumulation of capital (Knight, 2005).

The privatisation of state enterprises and basic services in South Africa will result in the majority of poor people being unable to afford services, and therefore dying of illnesses such as cholera, as they will not be able to pay for clean water. In some cases, privatisation has had deadly consequences. The worst cholera epidemic in South Africa's history broke out after water supplies were privatised, and made unavailable in poor rural communities (Cosatu, 2001).

According to the Western Cape Provincial Treasury (2005), South Africa's economic growth performance has improved over the past decade to an average of $2.9 \%$ over the period 1994 to 2003 compared with $1.1 \%$ of the preceding decade. However, the same report states that unemployment remains one of the most pressing socio-economic problems facing South Africa. It further argues that social ills such as poverty originate from lack of employment, which creates inequality. Further the same source states that the official unemployment rate in 1995 was $17 \%$; in 2000 it stood at $26 \%$ and $36 \%$ rising further to $42 \%$ in 2003 , and declining to $30 \%$ in 2004 (Western Cape Provincial Treasury, 2005). This means that unemployment is increasing overall, and jobs are not being created as predicted and a lack of 
jobs have other repercussion in the society such as crime, prostitution and so.

The lack of employment causes poverty and may also impact on the number of cases of HIV/Aids. Employment in South Africa is integral to people's livelihoods, both present and in the future. It is important to understand that job creation of the magnitude required for South Africa to meet the Millennium Development Goal and targets of halving the number of people living in poverty and unemployment by 2015 , let alone lifting the majority of people out of poverty, will be a long term project, and requires negotiation of factors within ourcontrol and those external, including global trade labour (Dercon, 2005).

Unemployment figures in South Africa are controversial. The level of unemployment is among the highest in the world, and many peg the actual unemployment rate much higher than current statistics. Officially, unemployment is only measured among people who are actively seeking employment. This can lead to the anomaly of the unemployment rate falling, yet there being little or no increase in the number of people with jobs (Labour force survey, 2004).

As indicated above, levels of unemployment are central markers of levels of poverty in South Africa. Unfortunately the last decadehas seen a steady increase in levels of unemployment in South Africa. Unemployment rose from 34.3\% of the total working age population in September 2000 to $40.5 \%$ in March 2005 (Frye, 2006). Recent Western Cape Provincial Treasury (2006) figures show that the Western Cape has reached about $26.3 \%$, with narrow unemployment $18.6 \%$, which compares favourably to the national situation where broad unemployment reached $41 \%$. Considering the employment data in 2004, about 1.7 million people were employed in the Western Cape. Approximately one half (50.6\%) are coloured, while 27.0\% percent are white and $21.1 \%$ percent are black making a total of $98.7 \%$ percent.

The September 2006 Quarterly Employment Statistics (QES) survey showed that the number of people employed in the formal non-agricultural business sector of the South African economy increased by about 73,000 persons or $1.0 \%$ from June 2006 (an estimated 7,285 employees) to September 2006 (an estimated 7,358 employees) (Pillay, 2007). In South Africa, unemployment is extremely high and it is seen as one of the most pressing socio-political problems facing the government. There has been a lively debate on the extent, nature, and cures of unemployment in South Africa but the outcome has been rather inconclusive. This reflects the lack of good empirical evidence in the past. The World Bank-funded SALDRU data collected in 1993 and subsequent October Household Surveys and Labour Force Surveys permit detailed microe-conomic and empirical analysis of unemployment in South Africa (Kingdon\& Knight, 2006). 
According to The Western Cape Provincial Treasury (2005) the official unemployment rate in 1995 was $17 \%$ while it expanded to $30 \%$ in 2004. In 2000 it stood at $26 \%$ per cent and 36 respectively raising it to a further $42 \%$ per cent in 2003 . These statistics mean that unemployment has increased, while jobs are not being created as predicted. In the Eastern Cape, which is one of the poorest provinces in South Africa, the clothing industry has been virtually wiped out (Horwitz, 2005).

\section{RESEARCH DESIGN AND METHODOLOGY}

A quantitative research method was used to determine the number of people affected directly or indirectly by the impact of privatisation. The method was considered so that a larger number of users could be reached. This was achieved by using a survey as the instrument of collecting data.

A questionnaire was designed with structured questions to gain information, and also to reach as many community members as possible. The survey outcomes were later analysed by a qualified statistician. The survey questionnaire was designed before going into the field. Initial visits were made to two sites. The questionnaire was designed to enable the researcher to collect data such as the affordability of services when provided by the government against the private sector; whether the community understood the concept of privatisation; whether privatisation had an impact on communities; whether it had created jobs, economic growth and created an income; and whether jobs had. The patterns and profiles of the users could not be obtained during the interview process.

In order to gain the confidence of the respondents and for ethical reasons, a confidentiality statement appeared on the cover.

Qualitative methodology was used as a tool to search and identify evidence of the effects of privatisation on the community of Khayelitsha. Interviews were conducted within the target group of the identified. The interview questions were structured in nature and strategically attempted to gain some insights into some of the issues suggested in the literature. Further, the questioning format was close and open-ended, which allowed for the emergence of unique and unanticipated issues. The interviews were transcribed and analysed for recurring themes. The survey instrument questionnaire was designed and developed by the researcher, while it was verified by a statistician and approved by the supervisor of the research study. After compiling the survey items, a pilot test was conducted on one (1) site, where twenty (20) respondents where questioned

The target population for this research was anyone ranging in age from eighteen and older situated in Khayelitsha. The study was therefore limited to the above-mentioned group. The type of sampling technique used for the survey implies that sample members should conform to certain 
criteria (Cooper \& Schindler, 2003). The survey questionnaires were only handed to community members who met these criteria. The target population were residents of Khayelitsha. 300 respondents were targeted and chosen via the random sampling technique. From the target group 148 responded to the questionnaire. This was a representative sample of the target population.

\section{DATA ANALYSIS}

The selected questionnaires from both group of respondents were organised and coded before inclusion in Excel format into the Statistical Package for Social Sciences (SPSS 14.0 version). The research population selected for the completion of the questionnaire constituted any persons resident of Khayelitsha, educated as well as uneducated, employed and unemployed, from 18 to over 80 . The double data entry were used to minimise errors and inaccuracy of results. This means that data from each respondent were inserted twice in separate spreadsheets of the Microsoft Excel program before importing them into SPSS. The analysis for the openended questions were done through content analysis and interpretation, by grouping similar responses into categories and assigning names to items that seemed to be related. With the closed ended questions the results were illustrated in tables and figures.

\section{ANALYSIS AND INTERPRETATION OF RESULTS Statement One}

Has privatisation affected you?

\section{Statistics}

\begin{tabular}{|c|c|c|}
\hline $\bar{N}$ & Valid & 148 \\
\hline & Missing & 0 \\
\hline
\end{tabular}

Table 1: Respondents view of how privatisation affected them

Has privatisation affected you?

\begin{tabular}{|ll|r|r|r|r|}
\hline & & & & $\begin{array}{c}\text { Cum ulative } \\
\text { Percent }\end{array}$ \\
\hline Valid & Yes & 29 & 19.6 & 19.6 & 19.6 \\
& No & 95 & 64.2 & 64.2 & 83.8 \\
& Dont know & 24 & 16.2 & 16.2 & 100.0 \\
& Total & 148 & 100.0 & 100.0 & \\
\hline
\end{tabular}

From the one hundred and forty-eight (148) respondents, one hundred and thirteen (113) did not respond to Statement one (1). There was a split response to the question. One respondent did not know. One preferred not to comment. A further twenty-nine (29) agreed that privatisation has affected 
them. Some said that they had been directly affected through retrenchment of a family member, neighbour or themselves, while others believed that they were affected because the price of electricity and other basic services, such as education, health, water, sanitation, transport and telecommunications had increased.

Due to privatisation, family members lose their jobs causing poverty to set in as they become unable to afford the cost of services. Some stated that the only reason private companies become interested in public enterprise is because of the profits. However, one (1) person believed that privatisation affected him/her in a positive way because it provided him/her with a job. This is a total contrast with the Table 1 where $64-2 \%$ have not been directly affected.

\section{Interpretation}

The results of this question are self-explanatory because they show how many people have been affected directly and indirectly, with most stating that privatisation affected them negatively. Their perception could be caused by limited or lack of knowledge about privatisation. However, the results emanating from the survey and reflected in Table 1 provide a different perspective and views.

\section{Statement Two}

Will the government reduce poverty and inequality in income redistribution through privatisation?

\section{Statistics}

Will Government Reduce poverty and inequality in income redis tribution through privatisation?

\begin{tabular}{|ll|r|}
\hline $\mathrm{N}$ & Valid & 144 \\
& Missing & 4 \\
\hline
\end{tabular}

Table 2: Respondents view on poverty and inequality in income redistribution

Will Government Reduce poverty and inequality in income redistribution through privatisation?

\begin{tabular}{|ll|r|r|r|r|}
\hline & & & & \multicolumn{2}{c|}{$\begin{array}{c}\text { Cumulative } \\
\text { Percent }\end{array}$} \\
\hline Valid & Yes & 42 & 28.4 & 29.2 & 29.2 \\
& No & 66 & 44.6 & 45.8 & 75.0 \\
& Dont know & 36 & 24.3 & 25.0 & 100.0 \\
& Total & 144 & 97.3 & 100.0 & \\
Missing & System & 4 & 2.7 & & \\
Total & & 148 & 100.0 & & \\
\hline
\end{tabular}


Of one hundred and forty-eight (148) respondents, forty-six (46) did not respond to the question. Three (3) of the respondents said that they are not certain; three (3) had no comment and one (1) did not know. Thirty-one (31) agreed that privatisation, as a government policy, can reduce poverty and inequality in income distribution because it creates jobs. The other sixtyone (61) did not agree with the statement and cited constant retrenchment. They believe that the government should be rendering services and not seeking profits. Therefore, they believe that the government should promote the welfare of their citizens.

One respondent raised the question of what evidence does the government have that suggests that privatisation works better than government-controlled environments. The respondent continues to say that privatisation is merely another scheme for the rich to become richer. He/she states that the government is not there for profit but to render service and promote the welfare of its citizen. Therefore, they can do a better job than the private service. One respondent asked what will happen if the owner or investor decided to withdraw from the country? What happen to jobs? Hence, the respondent advised direct local investment as solution. Another question from this respondent is what facts does the government have that privatisation is working better than government?

\section{Interpretation}

This statement is straightforward and the results from the respondents is a reflection of how ineffective the government has been with its policy and shows a lack of confidence on their ability to produce results with its macroeconomic policies. There could be a contributing factor in comparison to the number of respondents who believe that privatisation cannot reduce inequalities against those who believe that it does. Furthermore the study also shows that the perception is that the poor will not be able to afford services if the government privatises them. The answers reflect the general feeling of the respondents.

\section{Statement three}

Is privatisation good or bad for the poor? Why?

\section{Statistics}

Is privatisation Good or Bad for the poor?

\begin{tabular}{|ll|r|}
\hline $\mathrm{N}$ & Valid & 145 \\
& Missing & 3 \\
\hline
\end{tabular}


Table 3: Respondents view of privatisation whether is good or bad

Is privatisation Good or Bad for the poor?

\begin{tabular}{|c|c|c|c|c|c|}
\hline & & Frequency & Percent & Valid Percent & $\begin{array}{c}\text { Cumulative } \\
\text { Percent }\end{array}$ \\
\hline \multirow[t]{4}{*}{ Valid } & Good & 38 & 25.7 & 26.2 & 26.2 \\
\hline & Bad & 98 & 66.2 & 67.6 & 93.8 \\
\hline & Dont know & 9 & 6.1 & 6.2 & 100.0 \\
\hline & Total & 145 & 98.0 & 100.0 & \\
\hline Missing & System & 3 & 2.0 & & \\
\hline Total & & 148 & 100.0 & & \\
\hline
\end{tabular}

A total of four (4) respondents did not answer this question. However, ninety-four (94) respondents state that privatisation is bad for the poor because it takes from the poor and gives to the rich. An example cited was that CEO salaries and retrenchment cause poverty. They were unanimous that ordinary people will suffer since the rich get richer and basic services become too expensive for them. Families become disintegrated when the breadwinner loses his/her job and cannot afford to put food on the table. They further believe that privatisation causes retrenchment and exploitation due to the fact that most people work on a contract basis or have a temporary casual status. This information is supported with the results of the survey questionnaire where $67-6 \%$ percent agreed that privatisation is bad for the poor.

They stated that private companies do as they please so that they may gain and that privatisation increased the gap between rich and poor. One respondent from the group stated that if privatisation is monitored it can achieve its objective. Thirty-nine (39) believed that privatisation is good for the poor because it creates and increases job prospects and that privatisation does what the government cannot. It does not discriminate against anyone because one can get jobs regardless of race or education. Even though not everyone would benefit, it would reduce poverty and provide blacks with an opportunity to own companies, whereas the government does nothing for the people and only wants their votes.

The rest of the respondent, (10) ten, were uncertain as to whether privatisation was good because it creates jobs or bad because individuals also lose jobs because of it, particularly when they are breadwinners. They added that poverty increases when people are retrenched. They would support privatisation if its main purpose were to increase employment.

\section{Interpretation}

The overwhelming response of this research, including the results of 
this statement, can best be interpreted as a call for a change of course regarding the macro-economic policies and the government's commitment to improve the life of its citizens. This statement can also serve as an indicator as to how citizens view privatisation policies and its impact. Firstly, policies do not produce the expected results. Secondly, disagreement with the statement can be interpreted as a lack of confidence in the government and its macro-economic policies' ability to improve the lives of the citizens of this country.

\section{DISCUSSION}

Despite the efforts made by the South Africa government in trying to alleviate poverty and create jobs by growing the economy through putting in place related macro-economic policies, such as GEAR and its tenet privatisation. Government is expected to improve the lifes of its citizens, by attracting foreign direct investment, financial liberalization and so on. However the measures did not bring the expected results. To the contrary more people lost jobs and exploitation at the work place continue wherecasualisation in work places persist.

\section{RECOMMENDATIONS}

The following are the major recommendations, which emanate from the research study. This should be considered by government. It could assist the government's need for economic growth, poverty alleviation, while at the same time creating employment. Privatisation is unique since no single approach can be suggested because all models should be tested against the effect it has on the individual countries and its citizens.

The creation of jobs within the state sector itself is important where by individual employee are given jobs based on merit. Salaries should be market related. These will improve the quality of service, efficiency, and effectiveness.

By its own admission, GEAR and privatisation, specifically, have not met its target of job creation to eradicate poverty.

$>$ National enterprises should remain untouched because they were created to fulfil government duties.

$>$ Procedures, structures, and models should be implemented from recruitment and the evaluation of the staff to be employed. Appointing managers and setting contracts based on performance. Pay government employees and managers a competitive salary to avoid losing them to the private sector

$>$ The government should create a commercial wing and these enterprises should serve as instruments to market essential services and to raise enough capital to subsidise unproductive departments. A practical 
example is the existence of a commercial wing, South Africa Rugby Union(SARU) created.

$>$ The creation of public-private partnerships in certain areas that is of less national interest.

$>$ Cooperatives for specific people with specific needs and skills without the necessary resources.

$>$ The government should invest in creating more jobs in the public sector in order to diversify the investments, and run it efficiently and effectively in order to compete with the private sector but bearing in mind that it should make a profit whilst at the same time taking cognisance of its welfare responsibilities.

$>$ The creation of policies and regulations for local businesses that would provide radical support for small businesses and rewarding companies for purchasing local products and investing locally.

$>$ A rigid campaign should be established towards stimulating citizens'appreciation and support for local products and the effect it has on job-creation. Companies should be rewarded for the best and competitive prices, affordability and quality of products.

$>$ The creation of a quota for every international product which enters the country..

$>$ Subsidise the main sectors of the economy thus allowing them to give competitive prices and be on par with Western products, which are subsidised by their governments.

$>$ The government should review its policy and end privatisation in its present form. Should they continue with privatisation, a revised version should be implemented based on communal values and the African concept of UBUNTU.

$>$ Government departments that wish to privatise its operations, forms or methods, should do so by placing the interest of the people who work there or the surrounds first. This will assist the government to redistribute its resources equally and still achieve its objective of promoting the welfare of its citizens.

$>$ A socialist democratic system based on that of Scandinavian countries should be studied.

$>$ A political system that allows people to see facts rather than assumptions should be encouraged.

$>$ Finally, with the help of Statistics SA, government should study the impact of privatisation on poor communities and not focus on middle classes, or a questionnaire should be sent to universities and should be available on all government department websites for completion by anybody thereby ensuring greater community participation based on a wider view of people's needs and reactions. Furthermore privatisation is 
not an appropriate policy for a country like South Africa with its socioeconomic imbalances.

\section{CONCLUSION}

The researcher concludes from the empirical survey conducted that the community of Khayelitsha does not agree with the government's privatisation of basic services. It is imperative that the government should encourage national investment by local businesses and general entrepreneurship spirit. The government should design policies that enable small businesses to grow. Therefore, privatisation is not a blanket solution for the problems of poorly performing state-owned enterprise (SOEs).

Foreign investment is effective over a short term period. Investment can be transferred to a country, which seems viable for the owners of the business in most instances, whether it is locally or invests outside. The capital however is repatriated. Moreover, programmes that instill in the youth, from an early age, the idea of creating jobs through a school-designed curriculum, should be instituted. By so doing, more creativity and entrepreneurial spirit is inculcated into our minds. Jobs can be created without privatisation, in fact, privatising only leads to retrenchments as the literature showed as the focus of the new owners is on profits.

Privatisation gives the impression that the government's role is not to protect the welfare of its citizens. Models can be created that suite the country and trends that are applicable worldwide should not be followed. A model can be designed, which is suitable for South Africa where the majority of the population is poor. A democratic country can exists where its population owns all the state facilities without giving it away to the private sector whose only objective is to accumulate profits.

Finally, privatisation provokes more retrenchments than job creation and does not benefit the poor who cannot afford the services and cost of private companies. From the study it is clear that people prefer the government to provide services directly to them. Experiences show that privatisation is not advantageous for the poor. Neither does it create jobs. The conglomerates want to continuously accumulate capital at the expense of the poor. Therefore, the South African government should re-consider privatisation and find a model, which suits the economy as well as the country in the new constitutional democracy, where investment in the wellbeing of people and her prosperity is priority.

\section{References:}

1. Adelzadeh, A. (1997) Pros and cons of sell-offs weekly Mail and Guardian Available: http: web.sn.apc.org/wmail/issues/970424/bus3.html (28/04/2006) 
2. Bond, P. 2000. Elite transition: London. Pluto press

3. Brynard, P.1993. Privatisation in South Africa. School for Public Management and AdministrationUniversity of Pretoriahttp://www.unisa.ac.za 27/03/2007

4. Brynard, P. A. 1993. Privatisation and deregulation as part of economic reform. South African Journal of Economic and Management Sciences, $\quad 9, \quad$ autumn http://www.unisa.ac.za/Default.asp?Cmd=ViewContent\&ContentID= $11629[27 / 03 / 2007]$

5. Cosatu .2001. Privatisation is a killer. Cosatu Weekly, 17-24 August 2001http://www.queensu.ca/msp/pages/In_The_News/2001/August/k iller.htm [23/05/2006]

6. De Villiers, D .J. 1988. Privatiseringnodigvirekonomiesewelvaart. FinansiesenTegniek, 3 Junie 1988.

7. Dercon, S. 2005. Vulnerability: a micro perspective. Paper presented at the Annual Bank Conference on Development Economics, Amsterdam, and May 2005 http://www.economics.ox.ac.uk/members/stefan.dercon/vulnerability. pdf [10/06/2007]

8. Friye. I .2006. Poverty and unemployment in South Africa.

9. Hawley, S (2000) Exporting Corruption; Privatisation, Multinationals and Bribery, The Corner House (http://cornerhouse.icaap.org [20/06/2007]

10. Horwitz, F. 2005. Lessons from the Rex true form case: Cape time 22 March

11. Jurgens,A. 2006. GermanyProbes Alleged Kickbacks in South Africa Corvette Deal.http://www.corpwatch.org/article.php?id=13831 [08/04/2007]

12. Knigth, R. 2001. Impact and policy debates.

13. http:/richardknigth.homestead.com/files/sisaeconomiy.html 06/05/2006

14. Knigth, R. 2005. Economic policy and development. http:/richardknigth.homestead.com/files/sisaeconomiy.html [06/05/2006]

15. Kingdon, G. \& Knight, J.2006. The measurement of unemployment when unemployment is high. Labour Economics 3 (13):291-315,

16. Labour force Survey. 2004. Unemployment Balancing act http://www.southafrica.info/what_happening/news/unemploymentmarch2004.htm [04-08-2007]

17. Luiz,J.M. 2000. The politics of state, society and economy. International Journal of Social Economics 3(27):227-43.

18. McDonald, D. 2002. Who wants privatisation any way? Mail 
\&Guardian

11-17

October.

http//www.paddavis.de/dualism/activist_aesthectic/debate

[20/062006]

19. Marais, H. 1997. South Africa limits to change, the political economy of transformation. London: Zed books.Labour

20. Mcgregor, R\&Mcgregor,A. 1987 Privatisation in South Africa: juta

21. http://www.naledi.org.za/docs/Poverty Published in Infinite Energy Magazine Issue \#41) [18/04/2007]

22. Pillay, S. 2006. Quarterly employment statistics, December 2006. http://www.statssa.gov.za [27/03/ 2007]

23. SADTU 2001. Play the ball not the man: privatisation benefits elite. $\begin{array}{llll}\text { Media } & \text { release } & 24 & \text { August. }\end{array}$ http://www.queensu.ca/msp/pages/In_The_News/2001/August/sadtu. htm [26/7/2006].

24. Sikhakhane, M. F. 2001. The impact of globalisation on the ANC Government's macro-policy. M-tech thesis, University of Port Elizabeth, Port Elizabeth.

25. Streak C.J (2004). The Gear Legacy: did Gear fail or move South Africa forward in development? Cartax Publishing.

26. Sullivan, M (1994). Will there be a clearance sale? Financial Mail, 24 June. Office for Public Enterprises. 1995. Interview with Director: Public Enterprises, 7 February

27. Suppermaniam, M. (1999) Globalisation and economic liberation implications on the public service. http://www.jpa.gov.my/buletinjpa/bil2/globalisation_and_economic_1 iber.htm [04/08/2007]

28. UNDP. 2003. The challenge of sustainable development: Unlocking people's creativity. South Africa Human Development Report, Pretoria: OxfordUniversity Press. http://www.undp.org.za/NHDR2003/NHDRSumFull.pdf [27/08/2007].

29. Vinten,G. 2003. Enronitis-dispelling the disease: European Business School London. Managerial Auditing Journal. 7(18): 448-455.

30. Waters, A.R. 1987. The techniques of privatisation: economic impact. 61: 55-9

31. Western Cape provincial Treasury.2005. Provincial economic review \& outlook. Cape Town: Government printers.

32. Western Cape provincial Treasury.2006. Provincial economic review \& outlook. Cape Town: Government printers 